\title{
The quartz-dioritic Hospitais intrusion (SW Iberian Massif) and its mafic microgranular enclaves - Evidence for mineral clustering
}

\author{
P. Moita ${ }^{\text {a, }}$, J.F. Santos ${ }^{\text {b }}$, M.F. Pereira ${ }^{\text {c }}$, M.M. Costa ${ }^{\text {b,d }}$, F. Corfu ${ }^{\text {e }}$ \\ a HERCULES, Department of Geosciences, Évora University, Rua Romão Ramalho, 59, 7000-671 Évora, Portugal \\ b GEOBIOTEC, Department of Geosciences, Aveiro University, Portugal \\ c IDL, Department of Geosciences, Évora University, Portugal \\ d Centre for Star and Planet Formation, Natural History Museum of Denmark, University of Copenhagen, Denmark \\ e Department of Geosciences, University of Oslo, Norway
}

\section{A R T I C L E I N F O}

\section{Article history:}

Received 28 February 2014

Accepted 15 February 2015

Available online 27 February 2015

\section{Keywords:}

Mafic microgranular enclaves

Calc-alkaline granitoids

Mineral clustering

Hospitais quartz-diorite

Ossa-Morena Zone

$\mathrm{U}-\mathrm{Pb}$ zircon ages

\begin{abstract}
A B S T R A C T
The Hospitais pluton is an elliptical body, with its long axis oriented WNW-ESE, that belongs to the Évora Massif (Iberian Variscan belt). This intrusion has a quartz-dioritic composition, with plagioclase, quartz, amphibole (hornblende, but locally also cummingtonite) and biotite as the main mineral phases. Mafic microgranular enclaves in the quartz-diorite show the same minerals as the host, but with a greater abundance of amphibole and lower proportions of felsic minerals, especially quartz. U-Pb zircon ages obtained in one sample of the quartz-diorite and one sample of a mafic microgranular enclave gave identical ages, within error, of ca. 337 Ma. Geochemical data show that the quartz-diorite has a calc-alkaline signature with moderate enrichment in LILE/HFSE ratio $\left(\mathrm{Th}_{\mathrm{N}} / \mathrm{Y}_{\mathrm{N}}: 2.71-11.43\right)$ and clear negative Ti and $\mathrm{Nb}-\mathrm{Ta}$ anomalies $\left(\mathrm{Th}_{\mathrm{N}} / \mathrm{Nb}_{\mathrm{N}}\right.$ : 1.33-6.22). The composition of the enclaves shows that they do not represent direct melt compositions. Instead, their geochemical features (namely the abundances of Fe and Mn in variation diagrams and REE patterns in primitive mantle normalized diagrams) suggest that they correspond to mineral clustering formed during the previous crystallization stage of quartz-dioritic magma. Overlapping of mineral chemistry and $\mathrm{Sr}-\mathrm{Nd}$ isotope compositions in the quartz-diorite and the enclaves provides further support to that conclusion. The values for $\left.{ }^{87} \mathrm{Sr} /{ }^{86} \mathrm{Sr}\right]_{\mathrm{i}}$ and $\varepsilon \mathrm{Nd}_{\mathrm{i}}$ (calculated for $337 \mathrm{Ma}$ ) in the quartz-diorite vary from 0.706147 to 0.706491 and from -1.87 to -3.22 , respectively. This isotope composition may be explained either by differentiation of a mafic magma extracted from a mantle wedge enriched by long lasting subduction processes, or by mixing between a mafic magma from a depleted mantle source and a crustal melt. In the second case, the most likely source for the felsic component should be meta-igneous rocks, like the Lower Cambrian Alcáçovas orthogneisses that outcrop in neighbouring areas.
\end{abstract}

(C) 2015 Elsevier B.V. All rights reserved.

\section{Introduction}

Mafic microgranular enclaves (MME) hosted by granitoids such as quartz-diorites, tonalites and granodiorites have been profusely described and studied in the last four decades (e.g. Antunes et al., 2008; Barbey et al., 2008; Castro, 2013; Castro et al., 1990; Chen et al., 2009; Didier and Barbarin, 1991). Most of the prevailing models consider the MME as globules of mafic magma in a process of mixing/mingling between mantle- and crust-derived magmas (e.g. Barbarin, 2005; Castro et al., 1990; Chen et al., 2009; Didier and Barbarin, 1991). In this mechanism enclaves represent the early chilled intrusions along ascent conduits (Castro, 2013 and references included). Nevertheless, the origin of mafic microgranular enclaves has also been interpreted to represent refractory pods of a source rock (e.g. White et al., 1999) or the result

\footnotetext{
* Corresponding author. Tel.: + 351266745301

E-mail address: pmoita@uevora.pt (P. Moita).
}

of the accumulation of early formed minerals (Dahlquist, 2002; Dodge and Kistler, 1990).

Commonly, the MME-host granitoids correspond to calc-alkaline quartz-diorites to tonalites and granodiorites (e.g. Castro, 2013; Castro et al., 1991; Roberts et al., 2000) forming plutons emplaced in active continental margins and collisional orogens (Didier and Barbarin, 1991). The petrogenesis of quartz-diorites/tonalites in this geotectonic context has been ascribed mainly to (1) fractional crystallization from a sub-alkaline basaltic parental magma (e.g. Arth et al., 1978); (2) partial melting of mafic metamorphic rocks (amphibolitic or eclogitic assemblages; Rapp et al., 1991 and Drummond and Defant, 1990, respectively); (3) mixture and/or assimilation of crustal- and mantle-derived magmas (Bateman, 1995; Castro, 2013; Castro et al., 1990); and (4) partial melting from an already hybrid intermediate precursor (Castro, 2013).

In this work we present and discuss information gathered in the quartz-dioritic Hospitais intrusion, encompassing field data, petrographic observation, elemental and isotopic ( $\mathrm{Sr}-\mathrm{Nd}$ ) geochemistry, 